\title{
Temporal changes in vertical distribution, body orientation and mobility of pike (Esox lucius L.) free embryos: Individual observations under controlled conditions
}

\author{
C. Bry ${ }^{(1)}$, S. Davigny ${ }^{(1)}$ \\ Received February 25, 2010 / Reçu le 25 février 2010 \\ Revised July 7, 2010 / Révisé le 7 juillet 2010 \\ Accepted July 8, 2010 / Accepté le 8 juillet 2010
}

Key-words:

Esox lucius free embryos, 0+ pike, vertical distribution, attachment behaviour, eleutheroembryo mobility

\section{ABSTRACT}

The vertical distribution, body orientation and mobility of pike free embryos were studied at $10{ }^{\circ} \mathrm{C}$ in $25-\mathrm{cm}$ individual water columns. Five steps were identified: (1) a resting phase, up to day (D) 4 post-hatching; (2) an ascent phase (D1-D4); (3) a plateau (D5-D8), characterized by a wall-attachment behaviour in the subsurface zone; (4) a break-off phase (D9-D13); and (5) a final localization between mid-water and surface, corresponding to the air filling of the swim bladder and to the transition to active, horizontal swimming (D14-D17). Free embryos could be: side-lying (phase 1, late phase 4 and phase 5); lying upright (phases 4 and 5); vertically suspended with adhesion to the wall (phases $2-3$ and early phase 4 ); and in oblique or horizontal position (phase 5). The opening of mouth and anus occurred during phases 2 and 3 and swim bladder filling started on days 13-14. Free embryo mobility was low and stable during the first 5 days and increased regularly thereafter to reach maximal levels on days 14-16. This research provides evidence for a more complex and more variable temporal pattern of free embryo vertical distribution, posture and mobility than previously thought.

\section{RÉSUMÉ}

Évolution temporelle de la répartition verticale, de l'orientation corporelle et de la mobilité chez l'embryon libre du brochet (Esox lucius L.) : observations individuelles en conditions contrôlées

Mots-clés : embryons libres de Esox lucius, brochets $0+$, répartition verticale, comportement d'adhésion, mobilité des éleuthéroembryons
La répartition verticale, l'orientation corporelle et la mobilité de l'embryon libre de brochet ont été étudiées dans des colonnes d'eau individuelles de $25 \mathrm{~cm}$ à $10{ }^{\circ} \mathrm{C}$. Cinq étapes ont été identifiées : (1) une phase de repos, pouvant durer jusqu'à 4 jours $(\mathrm{J})$ après éclosion; (2) une phase ascensionnelle (J1-J4); (3) un plateau (J5-J8) caractérisé par un comportement d'adhésion à la paroi en subsurface; (4) une phase de rupture (J9-J13); et (5) une localisation finale entre la mi-profondeur et la surface, correspondant au remplissage de la vessie natatoire et au passage à une nage active dans le plan horizontal (J14-J17). Les orientations corporelles suivantes ont été observées : position allongée sur le flanc (phase 1, fin de phase 4, phase 5); position allongée sur l'abdomen (phases 4 et 5); suspension verticale avec adhésion aux parois (phases 2-3 et début de phase 4); et position oblique ou horizontale (phase 5). L'ouverture de la bouche puis de l'anus est intervenue

(1) INRA/Agrocampus Ouest, UMR Ecology and Ecosystems Health, 65 rue de Saint-Brieuc, CS 84215, 35042 Rennes cedex, France, Christian.Bry@rennes.inra.fr 
au cours des phases 2 et 3 et le remplissage de la vessie natatoire a débuté à J13 ou J14. Le degré de mobilité de l'embryon libre, peu élevé et stable au cours des 5 premiers jours, a ensuite augmenté de façon régulière pour atteindre les valeurs les plus élevées entre J14 et J16. La présente étude met en évidence pour la répartition spatiale, la posture et la mobilité de l'embryon libre l'existence d'une séquence temporelle plus complexe et plus variable que ne le suggéraient les connaissances antérieures.

\section{INTRODUCTION}

Pike, Esox lucius L., is one of the many fish species that fit into the category of "indirect ontogeny", as defined by Balon (1975) in his terminology of intervals of fish development. In this category, the embryonic period ends with an eleutheroembryonic phase, which takes place between hatching and the beginning of exogenous feeding. During this phase, the young fish undergoes considerable anatomical and physiological transformations that result in the achievement of a mobile larva, capable of gill respiration and of capturing live prey (Balon, 1984). A number of authors have described pike post-hatching ontogeny as a sequence of events including the opening of mouth and anus, the transition from yolk sac epithelium respiration to gill respiration, the appearance of vibrating pectoral fins, the air filling of the swim bladder and the progressive shift from yolk sac nutrition to exogenous feeding (Dorier, 1938; Monten, 1948; Chimits, 1951; Tschörtner, 1956; Gihr, 1957; Shamardina, 1957; Braum, 1964; Girsa, 1969; Balvay, 1983; Raat, 1988; Braum et al., 1996).

On the subject of spatial distribution, it has been unanimously noted that newly hatched pike typically move upward in the water column and attach themselves vertically to plant stems or leaves, or to decaying vegetation. Clearly, the presence of macrophytes is of utmost importance during this particular step of pike ontogeny (Bry, 1996; Craig, 2008) and emergent vegetative associations generally are a key component of nursery habitats (Casselman and Lewis, 1996). Attachment is made possible by the presence of cement secreting glands, a transient embryonic specialization. The adhesive cells or papillae are located on the front of the cephalic region and on both sides, slightly ahead of the eyes (Dorier, 1938; Monten, 1948; Tschörtner, 1956; Braum, 1964; Georges, 1964; Braum et al., 1996; Leslie and Gorrie, 1985; Cooper et al., 2008). Pike free embryos are reputed to be "inactive during the yolk-sac stage", until the transition from embryo to larva (Braum, 1978), and to spend a great part of yolk-sac stage "in a motionless position" (Raat, 1988; Braum et al., 1996). During the early post-hatching period, they were reported "to begin to swim only when the water is agitated" (Girsa, 1969).

However, previous works on pike eleutheroembryonic phase have been essentially qualitative, leaving a number of basic questions largely unanswered. "How high" exactly do pike free embryos rise in the water column? Despite their inactive appearance, do they undertake discrete changes in location and body orientation? How do they cope with transitional periods, such as the early post-hatching hours or the time of adhesive capacity loss? Finally, are morphological and behavioural changes strictly synchronized among individuals?

These questions highlight a definite need for a quantitative, disciplined and experimental approach. Accordingly, the objectives of the current study were (1) to investigate from a quantitative point of view the temporal patterns of free embryo vertical distribution between hatching and start feeding, and (2) to describe the changes in body orientation and mobility as a function of developmental time. Studying spatial distribution appeared as fully justified from an ecological standpoint, since the position of a free embryo in the water column will contribute to determine exposure to environmental conditions and might ultimately influence growth and survival (Chambers and Trippel, 1997). As the mean level of attachment of free embryos has been proposed as a tool to measure ecotoxicological responses (Amblard et al., 1998), a particular attention was paid to the maximum levels attained in the water column during attachment behaviour. Previous works dealt with observations on groups of free embryos; 
in contrast, we felt that individual-centered observations would provide a more precise insight into the studied biological phenomenons. We hypothesized that free moving young fishes, albeit embryos, would display a notable inter-individual variability in spatial position, body orientation and mobility during at least some periods of their development.

Since pike free embryos readily adhere to glass or plastic walls when in captivity (Bry, 1996), artificial water columns dedicated to monitoring pike individuals were used under controlled environmental conditions.

\section{MATERIALS AND METHODS}

\section{>PIKE EMBRYOS}

On five dates in February and March 2005, 10 broods of pike eggs originating from Le Boulet pike extensive culture facility (Fédération d'llle-et-Vilaine pour la Pêche et la Protection du Milieu Aquatique, western France), were brought in the laboratory a few days before hatching. Fertilization dates were 25 February (one brood), 3 March (2), 16 March (2), 22 March (1) and 29 March (4). Each batch consisted of ova from a single female inseminated with the pooled milt of three males and incubated in Zuger jars $\left(8-10^{\circ} \mathrm{C}\right)$ until 80 degree-days, then on fine mesh troughs. To minimize variability of early growth related to differences in egg size between lots (Rana, 1985), care was taken to use only females of relatively uniform weight $(c .1 .0 \mathrm{~kg})$.

\section{> EXPERIMENTAL SYSTEM}

All experiments were carried out between March and April in a cold room, temperature controlled at $10{ }^{\circ} \mathrm{C}$ with a $12: 12 \mathrm{~h}$ day/night lighting system (light on from 07h00 to $19 \mathrm{h00}$ ). Observation tubes consisted of translucent polyvinylchloride (PVC) cylinders (length, $30 \mathrm{~cm}$; inner diameter, $5.9 \mathrm{~cm}$ ) soldered to an opaque white PVC base at one end. Light originated from the ceiling of the room (800 lux, daylight neon tubes). However, as the observation tubes were translucent and set up on white reflective tables, there was no top-down light gradient within the tubes. Observation tubes were filled with dechlorinated tap water so as to constitute $25-\mathrm{cm}$ water columns (water volume: $680 \mathrm{~mL}$ ). They were used on an individual basis (one free embryo per tube) for the following reasons: (1) this procedure allowed to establish individual temporal patterns of body orientation and of position along the vertical axis; and (2) the trajectory of a given free embryo could not be influenced by displacements of other free embryos, as would have been the case in a multi-individual approach. The depth of $25 \mathrm{~cm}$ was selected as representative of the shallow waters $(5-60 \mathrm{~cm})$ where most pike spawning activity takes place (Raat, 1988; Bry, 1996). One day before the expected start of hatching, 25 embryos from a given brood were transferred to 25 tubes. Using a glass pipette (inner diameter: $5.5 \mathrm{~mm}$ ), each embryo was gently deposited on a weighted and slightly curved mesh support ( $15 \times 15 \mathrm{~mm} ; 1-\mathrm{mm}$ mesh) suspended in the tube at $5 \mathrm{~cm}$ above bottom. This procedure was followed in order to mimic the fact that immediately after fertilization pike eggs generally stick to the vegetation at some level in the water column, until hatching (Raat, 1988; Bry, 1996). Once a given free embryo had left the hatching site to cling to the tube wall, the corresponding mesh support was removed carefully.

Actual water temperature within experimental tubes ranged from 10.0 to $10.4{ }^{\circ} \mathrm{C}$. Dissolved oxygen concentrations were monitored occasionally within additional tubes stocked with a single free embryo: the levels generally ranged from 92 to $102 \%$ saturation $\left(10.6-11.6 \mathrm{mg} \cdot \mathrm{L}^{-1}\right)$; on rare occasions, lower levels (minimum: $71 \%$ saturation; $8.1 \mathrm{mg} \cdot \mathrm{L}^{-1}$ ) were recorded at the bottom of a tube with a permanently installed dissolved oxygen probe. Such levels have been shown to be fully adequate for pike early development to the first few days of feeding (Siefert et al., 1973). 


\section{> FREE EMBRYO OBSERVATIONS}

Sixteen vertical graduated scales (5-mm increments) were patterned at equal intervals on the walls of each experimental tube: this allowed us to measure both the vertical height of a free embryo above the bottom (to the nearest $2.5 \mathrm{~mm}$ ) and the embryo position on the horizontal circle passing through the fish (to the nearest $22.5^{\circ}$ ). Therefore, we were able to detect the possible displacements of a given free embryo between consecutive observations. The position and body orientation of each free embryo were noted each day at $14 \mathrm{~h} 00$, between one day post-hatching and start feeding. Five types of body orientation were identified: (1) sidelying on hatching site or on bottom; (2) lying upright on bottom; (3) vertical, with wall adhesion or occasional suspension to water surface; (4) oblique (head-up) or horizontal with wall adhesion; and (5) oblique or horizontal in open water.

A "mobility index" was defined as the percentage of pike free embryos displaying at least one change in position during a 2-hour period (12h00-14h00). Preliminary tests conducted on various observation periods (30-min, 2-hour, 24-hour) had shown that the 2-hour period yielded the most satisfactory index in terms of progressivity. The index was measured on five broods between day 1 and day 16 post-hatching. A change in position generally implied both a change in level in the water column and a change in circular position, but could also be limited to a change in circular position, especially when free embryos were nearing the surface.

Once hatching started in the embryo main stock, free embryos were classified into five subgroups according to hatching time and 10 individuals from the mid-hatching period were sampled and dedicated to the determination of first feeding date. Zooplankton ad libitum (mostly copepods and cladocerans, collected by using a $150-\mu \mathrm{m}$ mesh plankton net) was added on day 13 to the lot dedicated to feeding tests. Onset of exogenous feeding was defined as the first date when at least 5 of the 10 tested individuals showed the typical S-formed position of the body that immediately precedes predation attempts at this stage (Braum, 1964; Drost, 1987). The observation period of each 25 -free embryo group in individual water columns was terminated when feeding onset was detected in the dedicated lot, i.e. between day 15 and day 17 post-hatching.

For each brood, total length (TL) was measured to the nearest $0.1 \mathrm{~mm}$ at hatching and at the time of start feeding: ranges were $8.1-8.5 \mathrm{~mm}$ and $12.7-13.3 \mathrm{~mm}$, respectively.

On the day of tube stocking, 25 embryos from the same brood were assigned to five 5-L buckets: each lot, containing 5 individuals, was devoted to anatomical observations. On days $6,8,10,12$ and 14 post-hatching, 5 free embryos were examined under a Wild M3Z dissecting microscope with transmitted and reflected light, in order to determine the approximate dates of mouth and anus opening, and of initial swim bladder filling.

In March and April 2009, a complementary experiment involving four broods was performed at $10{ }^{\circ} \mathrm{C}$ in order to obtain data on free embryo distributions in $60-\mathrm{cm}$ water levels. A depth of $60 \mathrm{~cm}$ is considered as close to the upper depth limit of typical egg deposition in flooded areas and in small spawning ponds (Bry, 1996; Casselman and Lewis, 1996), although pike eggs may also be deposited in deeper littoral habitats (up to $6 \mathrm{~m}$ ) at the end of a protracted spawning season (Farrell et al., 2006). From each brood, 25 embryos were assigned to individual $60-\mathrm{cm}$ columns, and 10 to the determination of start feeding. In this experiment, free embryo observation was limited to vertical distribution between hatching and start feeding.

\section{> DATA ANALYSIS}

Heterogeneity in vertical distribution at a given date was expressed as the coefficient of variation (CV) in off-bottom distance, either between broods or between individuals. As free embryos within a brood could not be considered as independent, the longitudinal data related to vertical distribution were analyzed by using a mixed-model procedure (Sokal and Rohlf, 1995; SAS Institute, 2002). The Mann-Whitney U-test was used to compare off-bottom distances between $25-\mathrm{cm}$ and $60-\mathrm{cm}$ water columns. The Bartlett's test was used to compare variances 


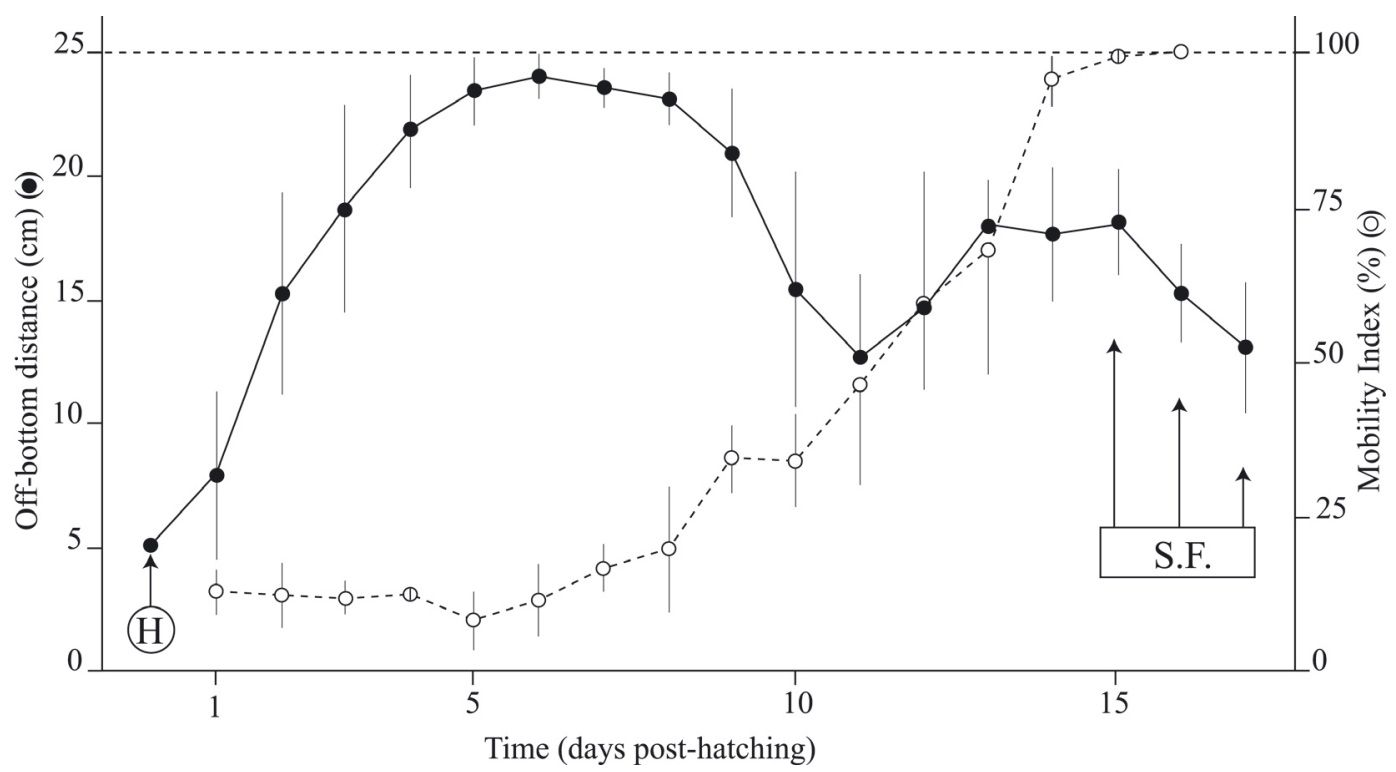

\section{Figure 1}

Vertical distribution (•) and mobility index (०) of pike free embryos in 25-cm water columns, between hatching $(H)$ and start feeding (S.F.) at $10^{\circ} \mathrm{C}$. Each data point represents the mean distance (with S.D.) above the bottom of 10 broods at $14 \mathrm{ho0}(n=25$ free embryos per brood) or the mean mobility index (with S.D.) of five broods for a 2-hour observation period (12h00-14h00). The mobility index was defined as the percentage of fish displaying at least one change in spatial position during a 2-hour period. Introduction into a translucent tube for individual observations involved the deposit of a pre-hatch embryo on a temporary support at $5 \mathrm{~cm}$ above the bottom. The interrupted horizontal line indicates the surface level at $25 \mathrm{~cm}$ or a mobility index of $100 \%$.

\section{Figure 1}

Répartition verticale d'embryons libres de brochet $(\bullet)$ et indicateur de mobilité (०) dans des colonnes d'eau de $25 \mathrm{~cm}$, entre l'éclosion $(\mathrm{H})$ et le début de l'alimentation exogène (S.F.) à $10{ }^{\circ} \mathrm{C}$. Chaque point représente la hauteur moyenne au-dessus du fond (avec écart-type) à 14h00 pour des embryons libres issus de 10 pontes ( $n=25$ embryons libres par ponte) ou l'indicateur moyen de mobilité (avec écarttype) pour des embryons libres issus de cinq pontes (période d'observation de 2 h : 12h00-14h00). L'indicateur de mobilité a été défini comme le pourcentage d'individus manifestant au moins un changement de position entre deux observations séparées par un intervalle de $2 \mathrm{~h}$. Au moment de son introduction en tube translucide d'observation individuelle, chaque embryon a été déposé peu avant l'éclosion sur un support temporaire, $5 \mathrm{~cm}$ au-dessus du fond. La ligne horizontale discontinue indique le niveau de la surface à $25 \mathrm{~cm}$ au-dessus du fond (répartition verticale), ou une valeur de $100 \%$ pour l'indicateur de mobilité.

related to vertical distances between the two experimental systems. All statistics were computed using the SAS statistical package (SAS Institute, 2002) and any $P$-value $<0.05$ was considered statistically significant.

\section{RESULTS}

\section{> VERTICAL DISTRIBUTION OF FREE EMBRYOS}

The overall pattern of vertical distribution, based on the means of daily positions of 250 free embryos between hatching and first feeding is presented on Figure 1. Changes in vertical distribution over time were highly significant $(P<0.01)$ and the temporal pattern was independent of egg batch $(P>0.05)$.

Five sequential steps were identified (Figures 1 [vertical distribution] and 2): (1) a resting phase, between a few hours and 4 days post-hatching; (2) an ascent phase (days 1-4); 


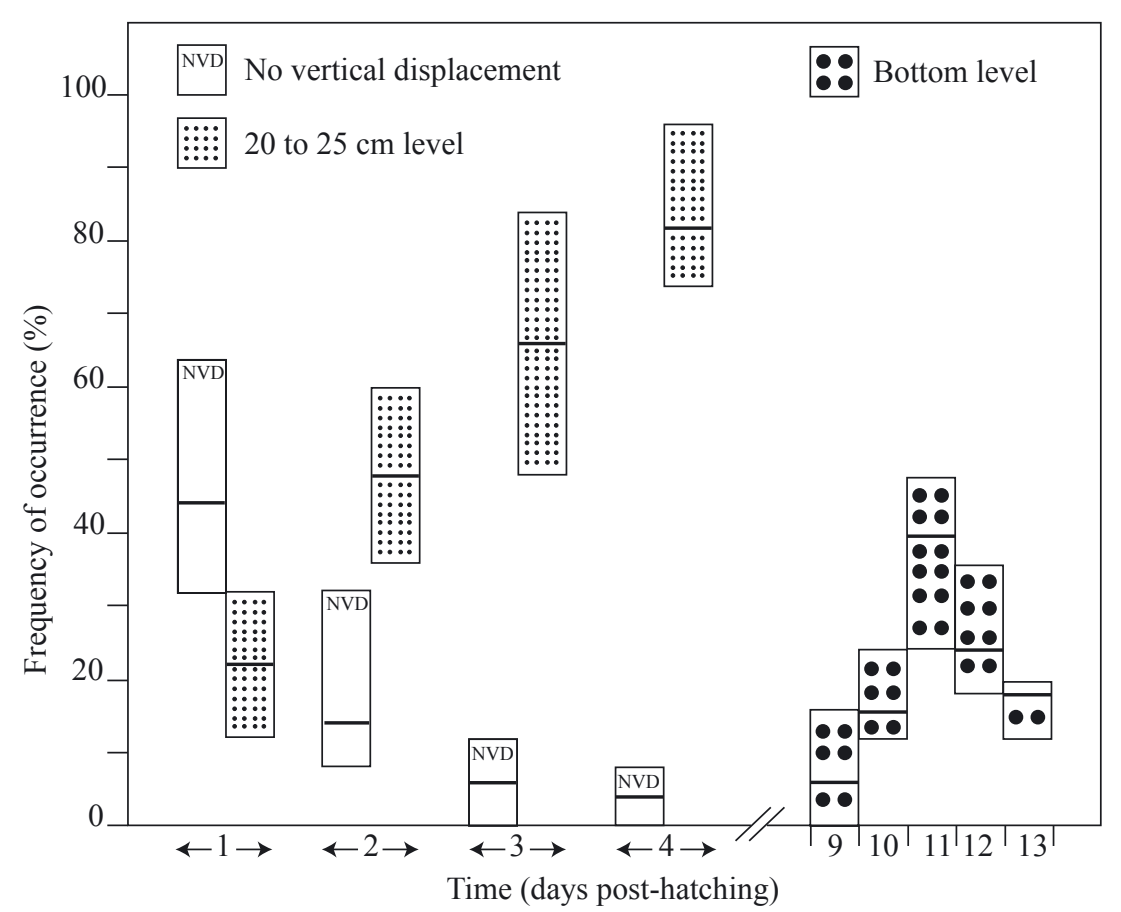

\section{Figure 2}

Resting, ascending and break-off phases: proportions of free embryos showing no vertical displacement (days 1-4 post-hatching), ascending to $20-25 \mathrm{~cm}$ above bottom (days 1-4), or localized at the bottom level (days 9-13). Data are presented as medians (indicated by horizontal lines within the bars) and interquartile ranges. Box plots are based on the observation of 10 broods (25 free embryos per brood).

\section{Figure 2}

Phases de repos, d'ascension et de rupture : proportions d'embryons libres n'effectuant aucun déplacement vertical (jours 1-4 après éclosion), s'élevant à 20-25 cm au-dessus du fond (jours 1-4), ou localisés au niveau du fond (jours 9-13). Les données sont présentées sous la forme de médianes (traits gras horizontaux à l'intérieur des rectangles) et d'écarts interquartiles (côtés horizontaux des rectangles). Elles sont basées sur l'observation de 10 pontes ( $n=25$ embryons libres par ponte).

(3) a plateau (days 5-8); (4) a sharply descending portion (break-off phase; days 9-11); and (5) from day 12 onwards a phase of fluctuating positions between mid-water and surface.

In Figure 1, time-related individual variability did obscure some important features of embryo vertical distribution: e.g., the occurrence of a post-hatching resting phase and of a postplateau drop to the bottom level. Therefore, further precisions on phases 1, 2 and 4 are given in Figure 2.

After hatching, the mean level of free embryos in the water column rose progressively (Figure 1). However, the ascent was far from being synchronized among individuals (Figure 2, left side): on day 1 , a relative majority of free embryos (47.6\%) was still resting on hatching site, whereas $21.8 \%$ had reached the upper portion of the water column $(20-25 \mathrm{~cm})$. Thereafter, the proportion of embryos showing no vertical displacement since hatching decreased steadily (4.4\% on day 4). Concomitantly, $81.8 \%$ were observed between 20 and $25 \mathrm{~cm}$ above bottom. It should be noted that a few individuals remained on hatching spot for up to 4-5 days before ascending. In agreement with the above description, the immediate post-hatching period was characterized by a high level of variability (Figure 3: between-brood CV $=44.6 \%, 27.5 \%$ and $23.0 \%$, on days 1, 2, 3, respectively; inter-individual mean CV $=130.4 \%, 66.1 \%$ and $45.3 \%$ ). Not a single free embryo failed to ascend: between day 2 and day 8 post-hatching, all of the 250 tested free embryos were observed at least once at a height between 22.5 and $25 \mathrm{~cm}$ (subsurface layer: $90-100 \%$ of water column height). 


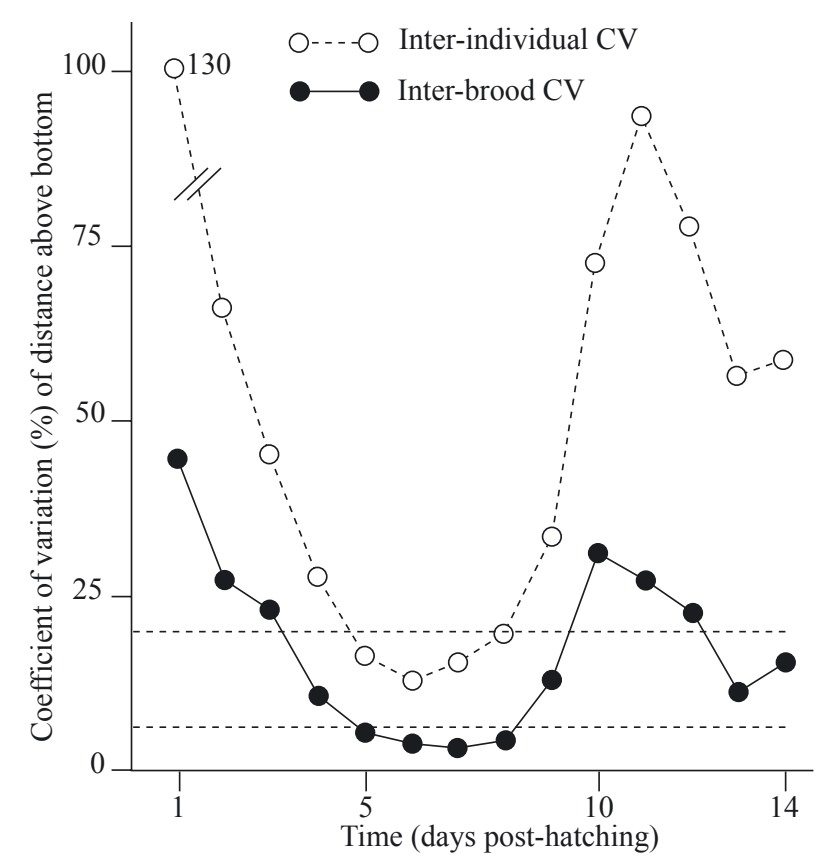

\section{Figure 3}

Temporal changes in the coefficient of variation (CV) of the vertical distance of free embryos above bottom between day 1 and day 14 post-hatching at $10{ }^{\circ} \mathrm{C}$. Solid curve: inter-brood CV. Interrupted curve: inter-individual mean CV. The two interrupted horizontal lines (CV $=6 \%$ and CV $=20 \%)$ indicate the upper CV levels during the plateau phase (days 5-8), between broods and between individuals, respectively. Data originate from the observation of 10 broods, each composed of 25 free embryos.

\section{Figure 3 \\ Profils temporels du coefficient de variation (CV) relatif à la hauteur des embryons libres au-dessus du fond, entre 1 et 14 jours après l'éclosion, à $10^{\circ} \mathrm{C}$. Courbe continue : CV inter-pontes. Courbe discon- tinue : CV inter-individus moyen. Les deux lignes horizontales discontinues (CV = $6 \%$ et CV = 20\%) indiquent les valeurs les plus élevées atteintes respectivement par le CV inter-pontes et le CV inter- individus moyen, au cours de la phase plateau (jours 5-8). Les données reposent sur l'observation de 10 pontes ( $n=25$ embryons libres par ponte).}

From day 5 to day 8 (plateau phase, Figure 3), spatial variability was minimal, both between broods (CV $<6 \%$ ) and between individuals (mean CV $<20 \%$ ). Mean off-bottom distance reached $23.4 \mathrm{~cm}$ by day 5 , and remained virtually unchanged until day 8 (Figure 1). The 4-day plateau had an overall level of $23.6 \mathrm{~cm}$ (i.e. $94.6 \%$ of water column height), and the proportion of fish reaching the subsurface layer at least one time between day 5 and day 8 was $98.8 \%$. During this phase, some free embryos were occasionally seen vertically suspended to the water surface by means of capillarity, without adhering to any wall.

The break-off phase was generally characterized by a passage through the zero level: from day 9 onwards, the proportion of free embryos positioned at the bottom level increased, peaked at $38.4 \%$ on day 11, and decreased thereafter (Figure 2, right side). Out of 250 free embryos, 187 (74.8\%) reached the zero level (bottom of tube) at least one time between day 9 and day 13. Another insight is provided by Figure 4, based on these 187 individual profiles synchronized according to the lowest level attained: in most cases, the transition from the plateau level to the zero level was a sharp phenomenon, occurring within $24 \mathrm{~h}$. It could also be quite progressive: up to 4 days in free embryo $n^{\circ} 11$ from brood $n^{\circ} 4$. Occasionally, a direct fall from $25 \mathrm{~cm}$ to the zero level was observed: a free embryo was seen losing wall-attachment, then dropping to the bottom within a few seconds, passively sinking head first. A similar variability in individual patterns of location shifts was noted after the break-off phase, during the second ascent period. In connection with the above-mentioned observations, inter-individual 


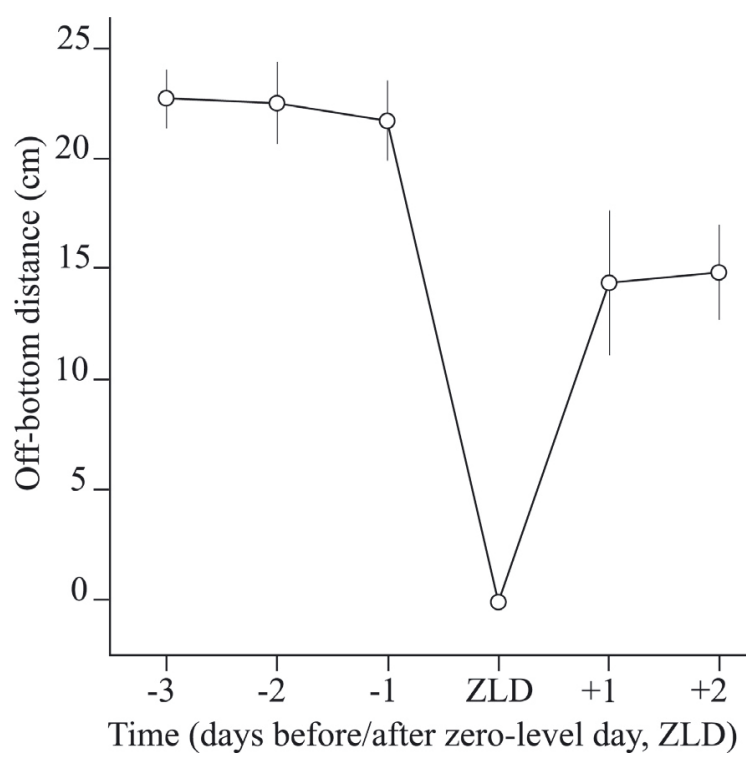

\section{Figure 4}

Break-off phase: vertical distribution of pike free embryos around the first zero-level day (ZLD). Individual profiles have been synchronized in reference to ZLD. Each data point represents the mean distance (with S.D.) above the bottom of 10 broods (17-24 free embryos per brood). Data originate from the 187 free embryos (74.8\% of total number) that reached the zero level at least one time between day 9 and day 13.

\section{Figure 4}

Phase de rupture : répartition verticale d'embryons libres de brochet autour du premier jour (ZLD) où le niveau zéro (niveau du fond) est atteint. Les profils individuels ont été synchronisés par rapport au jour ZLD. Chaque point représente la hauteur moyenne au-dessus du fond (avec écart-type) pour des embryons libres issus de 10 pontes ( $n=17-24$ embryons libres par ponte). Les données proviennent des profils des 187 embryons libres ( $74,8 \%$ de l'effectif total observé) qui ont atteint le niveau zéro au moins une fois entre le $9^{\mathrm{e}}$ et le $13^{\mathrm{e}}$ jour après éclosion.

variability rose again after the plateau period (Figure 3), with a mean CV peaking at $72.3 \%$, $93.3 \%$ and $77.2 \%$ on days 10,11 and 12 , respectively.

During phase 5, wall adhesion was either non-existing or very temporary. When a physical contact with the wall was noticeable, the bond appeared to be particularly loose, as the slightest external vibration induced detachment and repositioning in open water. On days 14-15, serial displacements to the surface were occasionally observed.

Table I shows the results of the comparison between $25-\mathrm{cm}$ and $60-\mathrm{cm}$ water columns, in terms of free embryo spatial distribution. In 60-cm columns, free embryos reached a significantly lower level in relation to total column height during the plateau phase (Mann-Whitney U-test, $P<0.05$ ) and the proportion of fish reaching the sub-surface layer was significantly lower than in $25-\mathrm{cm}$ columns $(P<0.01)$. A higher variability characterized off-bottom distances during the plateau period in $60-\mathrm{cm}$ columns (Bartlett's test, $P<0.05$ ).

\section{> FREE EMBRYO MOBILITY AND MOVEMENT TYPES}

Between day 1 and day 5 post-hatching, the mean index of mobility was relatively low and quite stable (8.7-13.0\%), as shown in Figure 1. From day 6 onwards, it increased almost continuously, reaching $68.2 \%$ on day 13 . Following a steep increase between day 13 and day 14 , mobility was maximal (94.5-100.0\%) during the last three days of observation.

From day 14 onwards, free embryos displayed darting swimming movements of short duration: this behaviour was observed in particular in the vicinity of bottom and surface. During phase 5 , high frequency vibrations of the pectorals as well as buccal and ocular movements, were occasionally observed. 


\section{Table I}

Vertical distribution of pike free embryos during the plateau phase, in relation to type of experimental system (25-cm and 60-cm water columns), and significance of between-systems differences. N: number of observations; $A O B D$ : absolute off-bottom distance (mean value $\pm S D, \mathrm{~cm}$ ); ROBD: relative off-bottom distance (mean value $\pm S D$, in \% of total column height); CV: coefficient of variation (\%) of relative offbottom distances; SSF: proportion of fish entering the subsurface zone at least one time between D5 and D8 (\%). The subsurface zone was defined as the water layer located between 90 and $100 \%$ of total column height.

\section{Tableau I}

Répartition verticale d'embryons libres de brochet au cours de la phase plateau, en fonction du type de système expérimental utilisé (colonnes d'eau de 25 et $60 \mathrm{~cm}$ ), et signification des différences intersystèmes. $N$ : nombre d'observations; AOBD : hauteur absolue au-dessus du fond (valeur moyenne $\pm \mathrm{ET}, \mathrm{cm}$ ); ROBD : hauteur relative au-dessus du fond (valeur moyenne $\pm \mathrm{ET}$, en $\%$ de la hauteur totale de la colonne d'eau); CV : coefficient de variation (\%) de la hauteur individuelle relative au-dessus du fond; SSF : proportion d'embryons libres localisés au moins une fois dans la zone de subsurface entre J5 et J8 (\%). La zone de subsurface est la couche d'eau comprise entre la surface et une hauteur égale à $90 \%$ de la hauteur totale.

\begin{tabular}{|l|c|c|c|c|c|}
\hline Experimental system and P-value & $N$ & AOBD $(\mathrm{cm})$ & ROBD $(\%)$ & Inter-individual CV (\%) & SSF (\%) \\
\hline 25-cm columns & 250 & $23.6 \pm 3.7$ & $94.6 \pm 14.7$ & 15.5 & 98.8 \\
\hline 60-cm columns & 100 & $32.3 \pm 21.4$ & $53.9 \pm 35.7$ & 66.2 & 26.9 \\
\hline $\boldsymbol{P}$-value & & & $<0.05$ & $<0.05$ & $<0.01$ \\
\hline
\end{tabular}

\section{> BODY ORIENTATION AND ANATOMICAL CHANGES}

As shown in Figure 5, free embryos could be: side-lying on hatching site or on bottom during phase 1, late phase 4 and phase 5 ; vertically suspended with adhesion to the walls of observation tubes during phases 2-3 and early phase 4; lying upright on bottom during phases 4 and 5; and in oblique or horizontal position, with little or no adhesion to the walls, during phase 5.

The opening of mouth and anus occurred during phases 2 and 3. Swim bladder filling was first detected on days 13-14.

\section{DISCUSSION}

\section{$>$ VERTICAL DISTRIBUTION AND PLATEAU PERIOD}

The present study unequivocally demonstrates that the vertical displacement undertaken by pike free embryos between a few hours and a few days after hatching is systematic and that each individual reaches a high level in the water column. While in $25-\mathrm{cm}$ waters the maximum level attained nearly always belonged to the subsurface zone, the average maximum height in $60-\mathrm{cm}$ waters was close to mid-column. Although spatial distribution was more variable in the deeper system, c. $27 \%$ of free embryos did reach the subsurface level: this achievement can be considered as remarkable since such a vertical migration represents, for a young fish with no sustained swimming ability, $c$. seventy-five times its own length.

The outcome of the $25 / 60 \mathrm{~cm}$ comparison (1) suggests that a stay of several days immediately below the surface, although a general rule in the shallowest waters, is not indispensable to normal development, and (2) shows that off-bottom remote positioning was experienced by all individuals in both experimental systems.

The minimal inter-individual and inter-brood variability recorded during the plateau period in $25-\mathrm{cm}$ water columns indicates a high degree of synchrony among free embryos at this time of their development. All the other phases $(1,2,4,5)$ were characterized by much higher levels of variability, particularly among individuals: after hatching, the embryo gains the capability to move freely from place to place and to experience changes in body orientation; a truly individual behaviour can then be expressed, with increased variability as a potential consequence. 


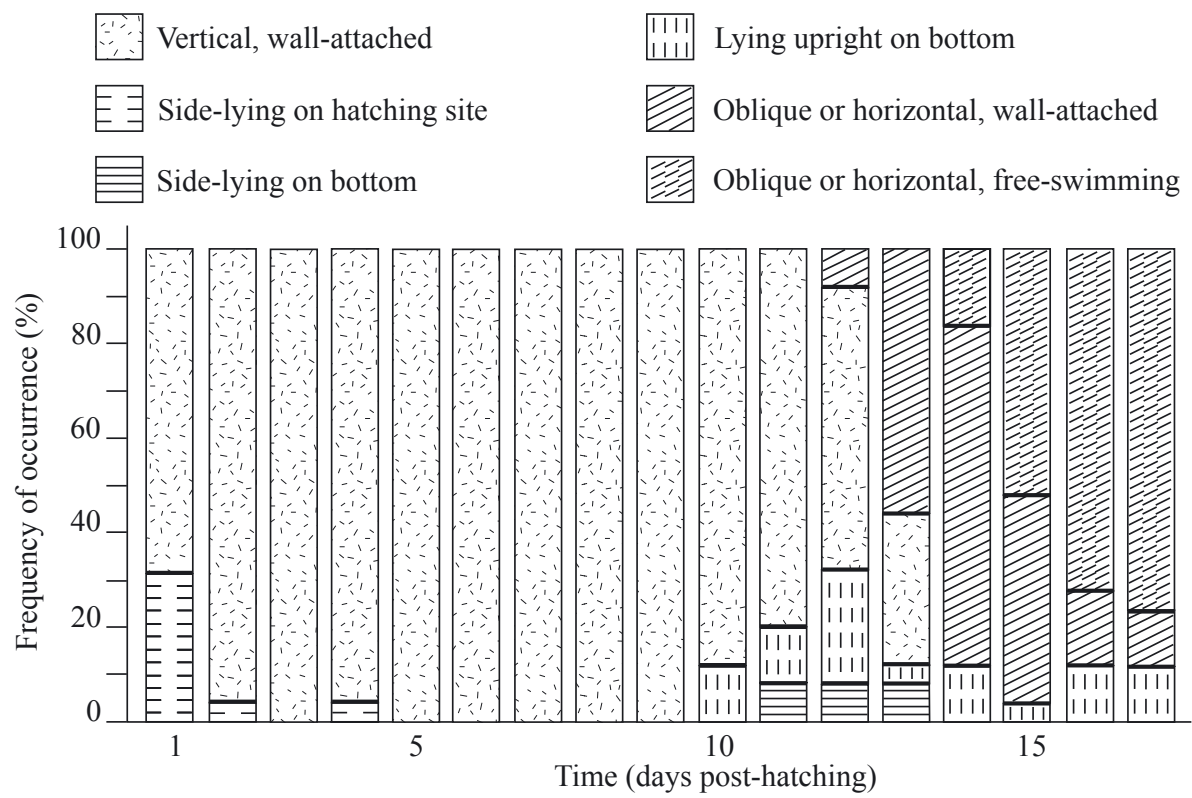

\section{Figure 5}

Changes in body orientation of pike free embryos (brood $n^{\circ} 8, n=25$ ) between hatching and start feeding at $10^{\circ} \mathrm{C}$. Each column shows the proportions of free embryos displaying various orientations on a given day. Observations of a separate lot from the same brood presented with zooplankton prey showed that exogenous feeding had not started by day 15 and concerned $50 \%$ of the fish on day 17.

\section{Figure 5}

Changements d'orientation corporelle en fonction du temps chez les embryons libres $(n=25)$ de la ponte $\mathrm{n}^{\circ} 8$, entre l'éclosion et le début de l'alimentation exogène à $10^{\circ} \mathrm{C}$. Chaque colonne indique pour un jour donné les proportions d'embryons libres adoptant différentes orientations corporelles. La mise en présence d'un autre lot d'embryons libres de la même ponte et de proies zooplanctoniques a montré que pour cette ponte l'alimentation exogène n'avait pas encore débuté au jour 15 après éclosion et concernait $50 \%$ des individus au jour 17.

The mean height of attachment of pike free embryos has been used as a biological indicator of insecticide neurotoxic effects (Amblard et al., 1998). The results of the present study strongly suggest, in an ecotoxicological context, to select the plateau phase (days $5-8$ at $10{ }^{\circ} \mathrm{C}$ ) for measuring the level of fixation, in order to take advantage of maximal, stabilized off-bottom distances with minimal variability and of a moderate mobility index throughout this period.

The presence of cement glands in free embryos is a key feature of early ontogeny of plant spawners (Balon, 1990). Attachment behaviour is believed to prevent them from drifting away (Braum, 1978) in the slow running waters of some spawning grounds (e.g. vegetated river banks sloping down gradually). This behaviour is also interpreted as an adaptation to the static conditions of many spawning areas, allowing free early stages to avoid oxygen-depleted bottom waters (Kennedy, 1969; Machniak, 1975; Billard, 1996; Braum et al., 1996; Bry, 1996). However, it is striking to see that free embryos can be exposed to the environmental conditions of the sediment-water interface on two occasions: (1) up to several days during the resting phase, following a fall down to the bottom as an egg at spawning time or as a newly hatched; and (2) during the most extreme part of the break-off phase (c. one day around day 11).

\section{> BREAK-OFF PHASE}

The break-off phenomenon (phase 4, from day 9 onwards), including a temporary stay at or near the zero level, is one of the unexpected findings of the present study. It is most certainly 
associated with the overall regression of adhesive organs and the exhaustion of secretion granules in remaining cells. According to the histological work of Georges (1964), the regression starts on day 9 at $c .10^{\circ} \mathrm{C}$ and is emphasized by day 11 , so that by day 14 adhesive cells have been replaced by regular epidermal cells. Secretory granules are more numerous before hatching and it is believed that secretion after hatching is only a remaining activity of the gland cells: this would explain the fact that repeated adhesive behaviour induced by artificial disturbance leads to the prolonged loss of fastening ability (Braum et al., 1996).

\section{> FREE EMBRYO MOBILITY}

One surprising result of our study is that free embryo mobility was never null or even close to zero, even during days of high position in the water column. Braum et al. (1996) stated that "fastened free embryos remain inactive" and that "40 individuals observed over 10 minutes each remained motionless during $99 \%$ of the observation time". The present study clearly shows that displacements do occur, including during attachment behaviour. However, this phenomenon can only be demonstrated by using a wider time scale of a few hours.

It should be noted that discrete daily increases in mobility started between day 5 and day 6 , i.e. during the plateau phase: this observation suggests that, although attached most of the time at this stage, free embryos were not fully inert but already engaged in dynamic processes. Most likely, the high mobility levels recorded on days 14-15 are to be related to the repeated visits to the surface, required for swim bladder filling.

\section{> FREE EMBRYO BEHAVIOUR IN THE NATURAL ENVIRONMENT}

Whether the observed patterns are fully representative of pike free embryo distribution in the field remains partly open to question. The vertical migration of free embryos in the water column appears to be a stereotyped, well established behaviour, and close inspections carried out in $8 \mathrm{~m}^{2}$ outdoor mesocosms planted with the helophyte Glyceria maxima and stocked with pike embryos have indeed allowed the detection of free embryos attached to vegetation within the subsurface layer (Bry, unpublished observations). The temporary presence of free embryos in the lowest layer is much more difficult to elucidate in a natural or semi-natural environment. One can only speculate that the density and structure of vegetation probably play a major role in this respect: in March-April, the short and dense vegetation of a newly flooded meadow might be more efficient to spare free embryos from contact with sediment than the scarce aquatic vegetation of a permanent water.

Although artificial, the experimental conditions of the current study proved satisfactory: no mortality was recorded, all free embryos exhibited a vertical migration and all late embryos tested for feeding successfully captured zooplanktonic prey. Another argument in favour of developmental normality lies in the fact that all timings of anatomical and behavioural changes were in good agreement with data previously reported under comparable water temperatures (Gihr, 1957; Shamardina, 1957; Balvay, 1983; Raat, 1988).

\section{ACKNOWLEDGEMENTS}

The authors wish to thank P.M. Lucas for the careful realization of the experimental set-up, M. Weber for producing quality illustrations and two anonymous referees for detailed and useful comments.

\section{REFERENCES}

Amblard G., Bry C., Toutant J.P. and Arpagaus M., 1998. Effets de l'exposition à un insecticide carbamate, le carbofuran, sur les performances de jeunes stades de brochet (Esox lucius L., 1758) : résultats préliminaires. Bull. Fr. Pêche Piscic., 350-351, 529-534. 
Balon E.K., 1975. Terminology of intervals in fish development. J. Fish. Res. Bd. Can., 32, 1663-1670.

Balon E.K., 1984. Reflections on some decisive events in the early life of fishes. Trans. Am. Fish. Soc., 113, 178-185.

Balon E.K., 1990. Epigenesis of an epigeneticist: the development of some alternative concepts on the early ontogeny and evolution of fishes. Guelph Ichthyol. Rev., 1, 1-42.

Balvay G., 1983. L'alimentation naturelle des alevins de brochet (Esox lucius L.) durant leur premier mois de vie. In: Billard R. (ed.), Le Brochet : Gestion dans le milieu naturel et élevage, INRA, Paris, 179-198.

Billard R., 1996. Reproduction of pike: gametogenesis, gamete biology and early development. In: Craig J.F. (ed.), Pike: Biology and exploitation, Chapman and Hall, London, 13-43.

Braum E., 1964. Experimentelle untersuchungen zur ersten nahrungsaufnahme und biologie an jungfischen von blaufelchen (Coregonus wartmanni Bloch), weissfelchen (Coregonus fera Jurine) und hechten (Esox lucius L.). Arch. Hydrobiol., Suppl. 28, 183-244.

Braum E., 1978. Ecological aspects of the survival of fish eggs, embryos and larvae. In: Gerking S.D. (ed.), Ecology of freshwater fish production, Blackwell Scientific Publications, Oxford, 102-131.

Braum E., Peters N. and Stolz M., 1996. The adhesive organ of larval pike Esox lucius L. (Pisces). Int. Rev. Gesam. Hydrobiol., 81, 101-108.

Bry C., 1996. Role of vegetation in the life cycle of pike. In: Craig J.F. (ed.), Pike: Biology and exploitation, Chapman and Hall, London, 45-68.

Casselman J.M. and Lewis C.A., 1996. Habitat requirements of northern pike (Esox lucius). Can. J. Fish. Aquat. Sci., 53 (Suppl. 1), 161-174.

Chambers R.C. and Trippel E.A., 1997. Early Life History and Recruitment in Fish Populations, Chapman and Hall, London, $596 \mathrm{p}$.

Chimits P., 1951. Quelques observations sur la fraye du brochet et le transport des œufs embryonnés. Bull. Fr. Piscic., 161, 135-143.

Cooper J.E., Mead J.V., Farrell J.M. and Werner R.G., 2008. Potential effects of spawning habitat changes on the segregation of northern pike (Esox lucius) and muskellunge (E. masquinongy) in the Upper St. Lawrence River. Hydrobiologia, 601, 41-53.

Craig J.F., 2008. A short review of pike ecology. Hydrobiologia, 601, 5-16.

Dorier A., 1938. À propos de l'œuf et de l'alevin de brochet. Bull. Fr. Piscic., 110, 61-73.

Drost M.R., 1987. Relation between aiming and catch success in larval fish. Can. J. Fish. Aquat. Sci., 44, 304-315.

Farrell J.M., Mead J.V. and Murry B.A., 2006. Protracted spawning of St. Lawrence River northern pike (Esox lucius): simulated effects on survival, growth, and production. Ecol. Freshwat. Fish, 15, 169-179.

Georges D., 1964. Évolution morphologique et histologique des organes adhésifs du brochet (Esox lucius L.). Travaux du Laboratoire d'Hydrobiologie et de Pisciculture de I'Université de Grenoble, 1964, 7-16.

Gihr M., 1957. Zur entwicklung des hechtes. Rev. Suisse Zool., 64, 355-474.

Girsa I.I., 1969. Reaction to light in some freshwater fishes in the course of early development and in altered physiological states. Problems of Ichthyology, 9, 126-135.

Kennedy M., 1969. Irish pike investigations. Spawning and early life history. Irish Fish. Invest., Ser. A (Freshwater), 5, 4-33.

Leslie J.K. and Gorrie J.F., 1985. Distinguishing features for separating protolarvae of three species of esocids. In: Kendall A.W. Jr. and Marliave J.B. (eds.), Descriptions of early life history stages of selected fishes: third international symposium on the early life history of fishes. Canadian Technical Report of Fisheries and Aquatic Sciences, 1359, 1-20.

Machniak K., 1975. The effects of hydroelectric development on the biology of northern fishes (reproduction and population dynamics). II. Northern pike Esox lucius (Linnaeus). A literature review and bibliography. Environment Canada, Fisheries and Marine Service Technical Report, 528, 1-82.

Monten E., 1948. Research on the biology and related problems of the northern pike. Skrifter Utgivna av Södra Sveriges Fiskeriförening, 1, 3-38 (in Swedish).

Raat A.J.P., 1988. Synopsis of biological data on the northern pike, Esox lucius Linnaeus, 1758. FAO Fish. Synop., 30, Rev. 2. 
Rana K.J., 1985. Influence of egg size on the growth, onset of feeding, point-of-no-return, and survival of unfed Oreochromis mossambicus fry. Aquaculture, 46, 119-131.

SAS Institute, Inc., 2002. The SAS system for Windows, version 9.1, SAS Institute, Cary.

Shamardina I.P., 1957. The developmental stages of the pike. Trudy Instituta Morfologii Zhivotnykh Akademii Nauk SSSR, 16, 237-298.

Siefert R.E., Spoor W.A. and Syrett R.F., 1973. Effects of reduced oxygen concentrations on northern pike (Esox lucius) embryos and larvae. J. Fish. Res. Bd. Can., 30, 849-852.

Sokal R.R. and Rohlf F.J., 1995. Biometry: the principles and practice of statistics in biological research, third edition, W.H. Freeman, New York, 887 p.

Tschörtner U., 1956. Untersuchungen über den einfluss einiger milieufaktoren auf die entwicklung des hechtes (Esox lucius L.). Arch. Hydrobiol., 24, 123-152. 